\title{
MENINGKATKAN PARTISIPASI BELAJAR PESERTA DIDIK MELALUI PENGGUNAAN MEDIA VIDEO YOUTUBE PADA MATA PELAJARAN PPKN DI KELAS X IPA 2 SMAN 2 PALANGKA RAYA
}

\author{
Oleh: \\ SAKMAN ${ }^{1}$, ARA $^{2}$ \\ ${ }^{1}$ Fakultas Keguruan dan Ilmu Pendidikan Universitas Palangka Raya (UPR) \\ e-mail: sakman@fkip.upr.ac.id \\ ${ }^{2}$ SMA Negeri 2 Palangka Raya, e-mail: dra.ara1965@gmail.com
}

\begin{abstract}
ABSTRAK: Salah satu permasalahan di kelas X IPA 2 SMA Negeri 2 Palangka Raya yaitu kurangnya partisipasi peserta didik dalam proses pembelajaran. Kegiatan peserta didik di dalam proses pembelajaran hanya terpusat pada kelompok yang menyampaikan presentasi makalah bahkan ada beberapa peserta didik yang bermain sendiri. Peserta didik cenderung pasif atau diam, tidak mau berinisiatif bertanya, apalagi menanggapi walaupun diberikan kesempatan untuk bertanya. Hal ini juga menunjukkan strategi pembelajaran yang digunakan oleh guru belum megoptimalkan keaktifan peserta didik, sehingga yang terjadi adalah komunikasi yang satu arah saja dan membuat suasana pembelajaran cenderung membosankan. Tindakan yang dapat dilakukan untuk mengatasi kondisi pembelajaran diatas yakni dengan mengorganisasikan kegiatan pembelajaran yang menarik, menyenangkan dan mampu membantu peserta didik dalam mengembangkan pemikirannya, pemahaman dan sikapnya sehingga mampu berpartisipasi secara aktif dalam setiap kegiatan pembelajaran. Oleh karena itu alternatif tindakan yang dilakukan adalah melaksanakan pembelajaran PPKn dengan menggunakan model pembelajaran kooperatif dengan media Video YouTube. Hasil penelitian menunjukkan bahwa terjadi peningkatan partisipasi belajar peserta didik (berdasarkan indikator penilaian) dari siklus I ke siklus II yakni $80 \%$ peserta didik berpartisipasi aktif dalam pembelajaran. Namun penting untuk juga diketahui bahwa peran guru sangat dibutuhkan terutama dalam membimbing peserta didik pada proses pembelajaran.
\end{abstract}

\section{KATA KUNCI: Partisipasi Belajar, Media Video YouTube, Pembelajaran PPKn}

ABSTRACT: One of the problems in Class X Science 2 of SMA Negeri 2 Palangka Raya is the lack of student participation in the learning process. The activities of students in the learning process are only centered on groups that deliver paper presentations and there are even some students who play alone. Students tend to be passive or silent, do not want to take the initiative to ask, let alone respond even though given the opportunity to ask. It also shows that the learning strategies used by the teacher have not yet optimized the activeness of students, so what happens is only one-way communication and makes the learning atmosphere tend to be boring. Actions that can be taken to overcome the above learning conditions are by organizing learning activities that are interesting, fun and able to assist students in developing their thinking, understanding and attitudes so that they are able to actively participate in each learning activity. Therefore the alternative action taken is to carry out PPKn learning using cooperative learning models with YouTube video media. The results showed that there was an increase in students' learning participation 
(based on assessment indicators) from cycle I to cycle II ie $80 \%$ of students actively participated in learning. But it is important to also know that the teacher's role is needed especially in guiding students in the learning process.

KEY WORDS: Learning Participation, YouTube Video Media, PPKn Learning

\section{PENDAHULUAN}

Terciptanaya
pembelajaran yang menyenangkan,
kreatif dan inovatif serta interaktif
merupakan tugas dari seorang guru.
Seorang Seorang guru yang melakukan pembelajaran seperti ini akan selalu di nantikan dan dirindukan oleh peserta didikanya di ruang kelas. Menciptakan suasana kelas yang interaktif pada peserta didik bukanlah sesuatu yang mudah, hal ini menjadi tantangan tersendiri bagi guru yaitu mampukah seorang guru menciptakan kondisi kelas, dimana terdapat hubungan timbal balik antara pendidik dan peserta didik dalam suatu kegiatan pembelajaran yang meneyenangkan.

Dalam kurikulum 2013 peserta didik dituntut agar berpartisifasi aktif dalam proses pembelajaran. hal ini mewajibkan seorang guru untuk melakukan pembelajaran yang kreatif dan inovatif yang dapat mengaktifkan peserta didik dalam proses pembelejaran. Guru hanya mengarahkan peserta didik dan peserta didik berpartisipasi aktif di kelas.

Salah satu permasalahan di kelas X IPA 2 SMA Negeri 2 Palangka Raya menunjukkan kurangnya partisipasi peserta didik dalam proses pembelajaran atau belum melibatkan peserta didik secara aktif dalam kegiatan belajar, sehingga partisipasi peserta didik dalam proses pembelajaran belum optimal. Kegiatan peserta didik di dalam proses pembelajaran hanya terpusat pada kelompok yang menyampaikan presentase bahkan ada beberapa peserta didik yang bermain sendiri. Peserta didik cenderung pasif atau diam, tidak mau berinisiatif bertanya, apalagi menanggapi walaupun diberikan kesempatan untuk bertanya. Hal ini juga menunjukkan strategi pembelajaran yang digunakan oleh guru belum megoptimalkan keaktifan peserta didik, sehingga yang terjadi adalah komunikasi yang satu arah saja.

Tindakan yang dapat dilakukan untuk mengatasi kondisi pembelajaran diatas yaitu dengan mengorganisasikan kegiatan pembelajaran yang menarik, menyenangkan yang mampu membantu peserta didik dalam mengembangkan pemikirannya, pemahaman dan sikapnya sehingga mampu berpartisipasi secara aktif dalam setiap kegiatan pembelajaran karena jika partisipasi peserta didik tidak ada maka setiap kegiatan pembelajaran tidak akan mencapai tujuan pembelajaran. Oleh karena itu alternatif tindakan yang dilakukan adalah melaksanakan pembelajaran PPkn dengan menerapkan pembelajaran dengan menggunakan media video Youtube. Pemilihan media pembelajaran ini dianggap tepat oleh peneliti karena prinsip pembelajarannya sesuai dengan kondisi kekenian dimana peserta didik senang menonton Youtube, kemudian siswa diminta untuk mengerjakan tugas secara berkelompok dengan tetap dibimbing oleh guru. Dengan demikian tuntutan siswa untuk aktif dalam pembelajaran dapat tercipta karena pola interaksi antara siswa sering terjadi.

Sesuai dengan alternatif tindakan diatas, serta dengan mempertimbangkan waktu, tempat dan tenaga yang dibutuhkan maka layak dilakukan suatu penelitian tindakan kelas tentang 
"Meningkatkan Partisipasi belajar Peserta didik Melalui Penggunaan Media Video Youtube pada mata Pelajaran PPkn Di kelas X IPA 2 SMA Negeri 2 Palangka Raya".

Berdasarkan uraian pada latar belakang, maka permasalahan dalam penelitian ini dirumuskan sebagai berikut: Apakah melalui Penggunaan Media Video Youtube dapat meningkatkan Partisipasi belajar peserta didik pada mata pelajaran PPKn di kelas X IPA 2 SMA Negeri 2 Palangka Raya?

\section{METODE PENELITIAN}

Penelitian ini Merupakan Penelitian Tidakan Kelas yang dilaksanakan di Kelas X IPA 2 SMA Negeri 2 Palangka Raya. Peserta didik dalam kelas ini berjumlah 42 orang yang terdiri dari 17 orang laki-laki dan 25 orang Perempuan. Penelitian ini dilaksanakan pada bulan September 2018. Adapun tahapan dalam penelitian ini adalah sebagai berikut:

(1) Perencanaan Penelitian: Kegiatan perencanaan meliputi: (a) Mengorganisir waktu pelaksanaan tindakan. (b) Melakukan diskusi dengan tim (Guru dengan Dosen). (c) Menentukan kelas subjek penelitian dan kompetensi dasar yang akan dijadikan fokus penelitian. (d) Mempersiapkan perangkat pembelajaran, mulai dari RPP, Silabus, LKS, buku bacaan peserta didik, media video dan lembar penilaian. (e) Membuat instrumen pengamatan/lembar obeservasi. (f) Mempersiapkan pengelolaan kelas, membuat skenario. $(\mathrm{g})$ Menetapkan cara pelaksanaan refleksi atau rencana tindak lanjut. (h) Menetapkan kriteria keberhasilan dan upaya pemecahan masalah.

(2) Pelaksanaan Tindakan, meliputi: (a) Membagi topik dalam beberapa bagian (sub topik). (b) Membentuk kelompok, Membagi peserta didik ke dalam kelompok-kelompok yang terdiri atas 4 sampai 5 orang per kelompok dengan cara heterogen. Menugaskan setiap peserta didik dalam kelompok untuk mengamati video pembelajaran dan mempelajari satu sub topik pelajaran. Memberi waktu kepada peserta didik untuk mempelajari apa yang menjadi bagiannya. (c) Meminta peserta didik untuk mempresentasikan topik hasil diskusi kelompok secara bergantian. Peserta didik lain diberi kesempatan untuk mengajukan pertanyaan sebagai klarifikasi. Guru mengelilingi satu kelompok ke kelompok lain untuk mengamati proses. Guru menyuruh peserta didik untuk membuat rangkuman dari hasil diskusi kelompoknya dan menyuruh perwakilan kelompok untuk menyampaikan kesimpulan diskusi. (d) Pada akhir pelajaran, Guru mengadakan kuis secara individual. hasil nilai yang diperoleh tiap anggota kelompok dikumpulkan, kemudian dirata-rata dalam kelompok untuk menentukan predikat kelompok. dalam menjawab kuis, anggota tidak boleh saling membantu. (e) Evaluasi oleh guru, Setelah dilakukan penghitungan skor dan penghargaan kelompok dilakukan evaluasi untuk menentukan langkah selanjutnya yang harus diterapkan agar diperoleh hasil tes yang lebih baik lagi.

Pada tahap pelaksanaan tindakan, dilaksanakan skenario pembelajaran sesuai perencanaan yang telah disusun pada tahap perencanaan di atas. Siklus I dilaksanakan selama 2 kali pertemuan atau 4 kali 45 Menit (180 Menit). Untuk siklus berikutnya disesuaikan dengan perkembangan siklus I.

Setiap pelaksanaan tindakan, baik siklus I (pertama) maupun siklus II (kedua) disertai dengan instrument penelitian berupa lembar observasi.

\section{HASIL PENELITIAN}


Hasil penelitian dapat kita lihat pada setiap pertemuan pada siklus I dan siklus II, setiap siklus dilaksanakan dua kali pertemuan. Pada pertemuan Siklus I dilaksanakan pengamatan atau observasi dengan menggunakan lembar observasi/pengamatan selama proses pembelajaran, mulai dari presentasi peserta didik dengan peserta didik bergantian dengan kelompok lain untuk tampil mempresentasikan hasil jawabannya dan semua kegiatan yang muncul terutama beberapa indikator keberhasilan yang diamati. Adapun hasil obeservasi yang dilakukan pada setiap tindakan dapat diuraikan sebagai berikut:

Untuk indikator peserta didik mengajukan pertanyaan atau tanggapan, data pengamatan pada siklus I menunjukkan setiap peserta didik masih kurang aktif dengan pencapaian kriteria keberhasilan dibawah ketuntasan seperti kategori tidak aktif presentase 9 persen, kurang aktif 74 persen, aktif 17 persen dan sangat aktif presentase 0 persen.

Begitu juga pada indikator peserta didik merespon tanggapan/ pertanyaan hasil pengamatan menunjukkan pada umumnya peserta didik merespon tanggapan/pertanyaan tingkat kriterianya masih kurang aktif dengan pencapaian kriteria keberhasilan dibawah ketuntasan seperti kategori tidak aktif presentase 10 persen, kurang aktif presentase 76 persen, aktif presentase 14 persen, dan sangat aktif presentase 0 persen.

Kemudian pada indikator peserta didik menyampaikan argumentasi atau pendapat hasil pengamatan menunjukkan pada umumnya peserta didik menyampaikan argumentasi atau pendapat tingkat kriterianya masih kurang aktif dengan pencapaian kriteria keberhasilan dibawah ketuntasan seperti kategori tidak aktif presentase 5 persen, kurang aktif presentase 78 persen, aktif presentase 17 persen, dan sangat aktif presentase 0 persen.
Selanjutnya pada indikator peserta didik bekerja sama dengan teman kelompok selama tindakan berlangsung, hasil pengamatan menunjukkan respon dari keseluruhan peserta didik masih dikategorikan kurang aktif, sebagaimana kategori tidak aktif presentase 3 persen, kurang aktif presentase 86 persen, aktif prsentase 3 persen, dan sangat aktif 0 persen.

Berdasarkan pada data tersebut diatas diambil kesimpulan bahwa dalam proses pembelajaran indikator keberhasilan peningkatan partisipasi peserta didik pada mata pelajaran PPKn di kelas tempat tindakan berlangsung pencapaian kriteria masih dikategorikan masih kurang. Hal ini menunjukkan beberapa kriteria dalam indikator keberhasilan dalam penelitian tindakan kelas belum terpenuhi, sehingga dapat diambil kesimpulan partisipasi peserta didik belum mengalami peningkatan secara signifikan sesuai yang diharapkan. Oleh karena itu perlu tindakan lanjutan yang sifatnya memperbaiki tindakan sebelumnya dengan harapan terjadi peningkatan partisipasi peserta didik di kelas penelitian diadakan.

Setelah mencermati hasil pengamatan (observasi) terhadap penggunaan Media video Youtube, yang dilakukan guru dalam kaitannya dengan usaha untuk meningkatkan partisipasi peserta didik dalam pembelajaran PPKn, berikut ini dikemukakan beberapa hal yang perlu dilakukan pada tahap (siklus II) kedua.

Kemudian pada hasil pengamatan peranan guru selama mengelola pembelajaran dengan mengguanakan Media video Youtube diperoleh informasi bahwa pelaksanaan pembelajaran untuk persiapan, kegiatan pendahuluan, kegiatan inti, keterampilan kooperatif, kegiatan akhir, pengelolaan waktu serta suasana kelas sudah baik namun masih belum maksimal. Yakni 
masih banyak dijumpai beberapa kekurangan dalam kegiatan pembelajaran didalam kelas yaitu sebagai berikut: (1) Guru masih terlalu mendominasi belajar mengajar sehingga peserta didik masih kurang diberi kesempatan untuk mengkonstruksi dan mengeksplorasi pengetahuannya. (2) Penggunaan waktu yang kurang efesien, sehingga banyak waktu yang terbuang. (3) Video pembeajaran yang ditayangkan masih perlu perbaikan, alat pembelajaran perlu dibenahi. (4) Masih banyak peserta didik yang memiliki kemampuan yang tinggi namun masih belum terbiasa untuk menyampaikan argumentasi dan memberi penjelasan kepada peserta didik lain sehingga suasana belajar masih kurang tercipta. (5) Masih belum terciptanya interaksi antara peserta didik dengan peserta didik secara maksimal karena peserta didik masih terkesan malu-malu dan kurang percaya diri karena belum terbiasa dengan model pembelajaran tersebut. (6) Peserta didik masih senang belajar sendiri, sehingga terkesan peserta didik sulit untuk terbiasa berbagi dengan pasangan kelompoknya. (7) Pemilihan topik pembahasan yang dikaji tiap kelompok kurang menantang peserta didik mengeksplorasi pengetahuan peserta didik, sehingga peserta didik masih banyak yang hanya sekedar menyalin dari buku bukan dari eksplorasi pikirannya. (8) Guru tidak konsisten dengan rencana yang telah diprogramkan dan terburu-buru.

\section{Hasil Penelitian Siklus II}

Hasil pengamatan tindakan pada siklus II diperoleh data respon peserta didik mengenai pencapaian indikator keberhasil peningkatan partisipasi siwa dalam pembelajaran PPKn sebagai berikut :

Untuk indikator peserta didik mengajukan pertanyaan atau tanggapan sesuai data pengamatan menunjukkan setiap peserta didik pada umumnya sudah aktif dengan pencapaian kriteria keberhasilan melebihi ketuntasan seperti, kategori sangat aktif presentase 36 persen, aktif presentase 52 persen, kurang aktif 10 persen dan tidak aktif presentase 2 persen.

Begitu juga pada indikator peserta didik merespon tanggapan/ pertanyaan hasil pengamatan menunjukkan setiap peserta didik pada umumnya sudah aktif dengan pencapaian kriteria keberhasilan melebihi ketuntasan seperti, kategori sangat aktif presentase 29 persen, aktif presentase 69 persen, kurang aktif 2 persen dan tidak aktif presentase 0 persen.

Kemudian pada indikator peserta didik menyampaikan argumentasi atau pendapat hasil data pengamatan menunjukkan pada umumnya menunjukkan setiap peserta didik pada umumnya sudah aktif dengan pencapaian kriteria keberhasilan melebihi ketuntasan seperti, kategori sangat aktif presentase 43 persen, aktif presentase 52 persen, kurang aktif 5 persen dan tidak aktif presentase 0 persen.

Kemudian pada indikator peserta didik bekerja sama dengan teman kelompok selama tindakan berlangsung hasil pengamatan menunjukkan pada umumnya data pengamatan menunjukkan setiap peserta didik sudah aktif dengan pencapaian kriteria keberhasilan melebihi ketuntasan seperti, kategori sangat aktif presentase 55 persen, aktif presentase 40 persen, kurang aktif 5 persen dan tidak aktif presentase 0 persen.

Berdasarkan pada hasil tindakan siklus II yang dipaparkan pada uraian diatas, indikator keberhasilan yang telah diamati menunjukkan peningkatan partisipasi peserta didik pada kelas tempat tindakan berlangsung dengan peningkatan yang sangat signifikan dibandingkan pada tindakan siklus I. Tindakan pada siklus II telah berhasil hal itu tampak pencapaian kategori sangat 
aktif, aktif untuk setiap indikator meningkat dari keseluruhan peserta didik yang diamati, sehingga dapat diambil kesimpulan bahwa partisipasi peserta didik dalam pembelajaran PPKn mengalami peningkatan yang sangat drastis.

\section{PEMBAHASAN}

Berdasarkan data hasil penelitian yang dipaparkan sebelumnya ditemukan bahwa melalui penggunaan Media video Youtube dapat meningkatkan partisipasi belajar peserta didik kelas X IPA 2 SMAN 2 Palangka Raya dari siklus I ke siklus II.

Tabel. 1.1. Sebaran hasil yang dicapai pada siklus I dan siklus II

\begin{tabular}{|c|c|c|c|c|c|c|}
\hline \multirow{3}{*}{ No } & \multirow{3}{*}{$\begin{array}{l}\text { Indikator Yang } \\
\text { Diamati }\end{array}$} & \multirow{3}{*}{$\begin{array}{l}\text { Kategori } \\
\text { Pencapaian }\end{array}$} & \multicolumn{4}{|c|}{ Siklus } \\
\hline & & & \multicolumn{2}{|c|}{ Siklus I } & \multicolumn{2}{|c|}{ Siklus II } \\
\hline & & & Absolut & Relatif & Absolut & Relatif \\
\hline \multirow[t]{4}{*}{1} & \multirow{4}{*}{$\begin{array}{l}\text { Mengajukan } \\
\text { pertanyaan atau } \\
\text { tanggapan }\end{array}$} & Sangat aktif & 0 & $0 \%$ & 15 & $36 \%$ \\
\hline & & Aktif & 7 & $17 \%$ & 22 & $52 \%$ \\
\hline & & Kurang aktif & 31 & $74 \%$ & 4 & $10 \%$ \\
\hline & & Tidak aktif & 4 & $9 \%$ & 1 & $2 \%$ \\
\hline \multirow[t]{4}{*}{2} & \multirow{4}{*}{$\begin{array}{l}\text { Merespon } \\
\text { tanggapan/pertanyaan }\end{array}$} & Sangat aktif & 0 & 0 & 12 & $29 \%$ \\
\hline & & Aktif & 6 & $14 \%$ & 29 & $69 \%$ \\
\hline & & Kurang aktif & 32 & $76 \%$ & 1 & $2 \%$ \\
\hline & & Tidak aktif & 4 & $10 \%$ & 0 & 0 \\
\hline \multirow[t]{4}{*}{3} & \multirow{4}{*}{$\begin{array}{l}\text { Menyampaikan } \\
\text { argumentasi atau } \\
\text { pendapat }\end{array}$} & Sangat aktif & 0 & 0 & 18 & $43 \%$ \\
\hline & & Aktif & 7 & $17 \%$ & 22 & $52 \%$ \\
\hline & & Kurang aktif & 33 & $78 \%$ & 2 & $5 \%$ \\
\hline & & Tidak aktif & 2 & $5 \%$ & 0 & 0 \\
\hline \multirow[t]{4}{*}{4} & \multirow{4}{*}{$\begin{array}{l}\text { Bekerja sama dengan } \\
\text { teman kelompok }\end{array}$} & Sangat aktif & 0 & 0 & 23 & $55 \%$ \\
\hline & & Aktif & 5 & $11 \%$ & 17 & $40 \%$ \\
\hline & & Kurang aktif & 36 & $86 \%$ & 2 & $5 \%$ \\
\hline & & Tidak aktif & 1 & $3 \%$ & 0 & 0 \\
\hline
\end{tabular}

Sumber : Hasil observasi bulan September 2018

Dari keempat indikator partisipasi peserta didik yang diamati selama pelaksanaan tindakan di kelas menggambarkan peningkatan pencapaian kategori kriteria keberhasilan sebagaimana yang diharapkan dari siklus I sampai siklus II. Pada siklus II terdapat peningkatan pencapaian indikator keberhasilan dari keseluruhan peserta didik yang diamati sangat tinggi.

Sehingga apabila dikaitkan dengan kriteria keberhasilan dalam penelitian ini, ternyata sampai dengan siklus II peserta didik telah mencapai kategori meningkat. Berdasarkan uraian diatas, dari empat indikator keberhasilan yang telah ditetapkan kriteria keberhasilan telah tercapai, maka disimpulkan bahwa partisipasi peserta didik mengalami peningkatan dengan kriteria meningkat.

Dengan demikian penerapan pembelajaran dengan menggunakan Media video Youtube dalam pembelajaran PPKn dapat meningkatkan partisipasi peserta didik. Maka hasil ini pula menunjukkan adanya keterkaitan erat dengan pencapaian hipotesis yang 
diajukan dalam penelitian ini yaitu "Meningkatkan Partisipasi belajar Peserta didik Melalui penggunaan media video Youtube pada mata Pelajaran PPkn Di kelas X IPA 2 SMAN 2 Palangka Raya".

Namun yang penting pula dalam keberhasilan ini harus didukung pembimbingan yang baik dari guru selama proses belajar berlangsung utamanya pada saat peserta didik mengamati video Youtube dan pada saat kerja berkelompok. Pembimbingan guru selama pembelajaran dapat mendorong peserta didik untuk lebih meningkatkan partisipasi peserta didik dalam belajar.

\section{PENUTUP}

(1) Penerapan pembelajaran dengan menggunakan media video Youtube dapat meningkatkan partisipasi peserta didik dalam pembelajaran PPKn peserta didik kelas X IPA 2 SMA Negeri 2 Palangka Raya. (2) Partisipasi peserta didik dalam pembelajaran PPKn meningkat pada tindakan siklus II dengan indikator keberhasilan seperti: 1) Peserta didik mengajukan pertanyaan atau tanggapan hasil pengamatan menunjukkan peningkatan meningkat, 2) Peserta didik merespon tanggapan/pertanyaan hasil pengamatan dari keseluruhan peserta didik menunjukkan peningkatan kriteria meningkat, 3) Peserta didik menyampaikan argumentasi atau pendapat hasil pengamatan dari keseluruhan peserta didik menunjukkan peningkatan kriteria meningkat, 4) Peserta didik bekerja sama dengan teman kelompok hasil pengamatan dari keseluruhan peserta didik menunjukkan peningkatan kriteria sangat meningkat.

Berdasarkan kesimpulan dan implikasi dalam penelitian ini, beberapa saran yang dapat dipertimbangkan dalam meningkatkan hasil belajar peserta didik di kelas X IPA 2 SMAN 2 Palangka Raya sebagai berikut. Pembelajaran lebih ditekankan pada aktivitas belajar dengan penggunaan media video Youtube secara maksimal dan lebih ditingkatkan, artinya dengan adanya keseimbangan antara aktivitas fisik dan aktivitas mental yang pada akhirnya akan meningkatkan hasil belajar peserta didik.

\section{DAFTAR PUSTAKA}

Abdul Majid. 2013. Strategi pembelajaran. Bandung; PT remaja Rosdakarya

Arikunto. dkk. 2009. Penelitian Tindakan Kelas. Jakarta: Bumi Aksara.

Arikunto, Suharsimi. 2006. Prosedur Penelitian Suatu Pendekatan Praktik. Mataram: Rineka Cipta

Aziz Wahab dan Udin S. 2002. Pendidikan Pancasila dan Kewarganegaraan (PPKn). Jakarta: Universitas Terbuka

Bruce Joyce, dkk diterjemahkan Achmad Fawaid dan Ateilla Mirza. 2009. Model of Teaching Model-model pengajaran Edisi Delapan, Yogyakarta: Pustaka Pelajar

Departemen Pendidikan Nasional. 2009. Model-model pembelajaran IPS/PKn

Etin Solihatin dan Raharjo. 2008. Analisis Model pembelajaran IPS, Jakarta: Bumi Aksara.

Etin, Solihatin. 2012. Strategi Pembelajaran PPKn, Jakarta: Bumi Aksara

Hamalik, Oemar. 1993. Strategi Belajar Mengajar: Mandar Maju

Kaelan. 2007.2 Pendidikan Kewarganegaraan, Yogyakarta: Paradigma

Masnur Muslich. 2009. Melaksanakan Penelitian Tindakan Kelas itu Mudah. Jakarta: Bumi Aksaras 
Ngalim, Purwanto. 2002. Ilmu Pendidikan Teoritis dan Praktis, Bandung: Remaja Rosdakarya Miftahul, Huda. 2013. Cooperative Learning, Yogyakarta: Pustaka Pelajar.

Paisaluddin dan Ermalinda. 2013. Penelitian Tindakan Kelas (Classroom Action Reseach), Bandung: Alfabeta.

Robert E.Slavin diterjemahkan oleh Narulita Yusron. 2005. Cooperative Learning : theory, research and practice. Bandung: Nusa Media
Rochiati, Wiriaatmadja. 2012. Metode Penelitian Tindakan Kelas, Bandung: PT Remaja Rosdakarya

Trianto. 2007. Model-model pembelajaran Inovatif Berorientasi Konstuktivistik. Jakarta; Prestasi Pustaka Publisher

Trianto. 2012. Mendesain Model Pembelajaran InovatifProgresif. Jakarta: Kencana Prenada Media Group

Zainal, Aqib. 2008. Penelitian Tindakan Kelas, Bandung: Yrama Wi 